\title{
Impact of social isolation by Coronavirus disease 2019 in food: a narrative review
}

\author{
Impacto do isolamento social pela Coronavirus \\ disease 2019 na alimentação: uma \\ revisão narrativa
}

\author{
Luísa Harumi MATSUO ${ }^{1}$ ID 0000-0003-4825-6729 \\ Camila TURECK ${ }^{1}$ ID 0000-0002-5672-1400 \\ Luana Pucci de LIMA1 ID 0000-0002-3914-2554 \\ Patrícia de Fragas HINNIG ${ }^{1}$ ID 0000-0002-9348-8513 \\ Erasmo Benicio Santos de Moraes TRINDADE ${ }^{1}$ (D) 0000-0003-1736-4049 \\ Francisco de Assis Guedes de VASCONCELOS ${ }^{1}$ (ID) 0000-0002-6162-8067
}

\section{A B S T R A C T}

The objective of this narrative review, with a systematic survey, was to investigate the impact of social isolation on food (eating habits) during the 2019 Coronavirus disease pandemic. A retrieval of studies published from January $1^{\text {st }}, 2019$ to June $18^{\text {th }}, 2020$ was carried out in the PubMed, Web of Science and Embase databases. The screening was structured using the terms corresponding to Coronavirus disease 2019, social isolation and food. All steps were carried out independently by three reviewers. Twelve studies were included, totaling 20,789 people assessed, with a predominance of cross-sectional studies of adult population. The studies reviewed had been carried out in Italy $(n=4)$, Spain $(n=2)$, Poland $(n=1)$, China $(n=1)$, India $(n=1)$, United States of America $(n=1)$, South Africa $(n=1)$ and in a continental multicenter $(n=1)$. The analysis of the studies included showed that most people reported that they did not change their usual diet; in addition, an increase in cooking habits, consumption of fruits and vegetables and a decrease in the consumption of alcoholic beverages was observed. A decrease in fish consumption and an increase in comfort foods were also reported. It was found that food habits changed in times of social isolation. We suggest that new

\footnotetext{
1 Universidade Federal de Santa Catarina, Centro de Ciências da Saúde, Programa de Pós-Graduação em Nutrição. Campus Universitário Reitor João David Ferreira Lima, R. Eng. Agronômico Andrei Cristian Ferreira, s/n., Trindade, 88040-900, Florianópolis, SC, Brasil. Correspondence to: F.A.G. VASCONCELOS. E-mail: <f.vasconcelos@ufsc.br>.

Support: Conselho Nacional Brasileiro de Desenvolvimento Científico e Tecnológico (CNPq, National Council for Scientific and Technological Development) (Process n. 303233/2019-2).

How to cite this article

Matsuo LH, Tureck C, Lima LP, Hinnig PF, Trindade EBSM, Vasconcelos FAG. Impact of social isolation by Coronavirus disease 2019 in food: a narrative review. Rev Nutr. 2021;34:e200211. https://doi.org/10.1590/1678-9865202134e200211
} 
investigations be carried out in different socioeconomic and demographic frameworks. We propose to continue the study on this theme, with a systematic review with or without meta-analysis.

Keywords: Coronavirus infections. Diet, food and nutrition. Review. Social isolation.

\section{RE S U M O}

Trata-se de revisão narrativa com busca sistemática, tendo por objetivo investigar o impacto do isolamento social na alimentação (hábitos alimentares) durante a pandemia da Coronavirus Disease 2019. Foi realizado rastreio de estudos publicados no período de $1^{\circ}$ de janeiro de 2019 a 18 de junho de 2020 nas bases PubMed, Web of Science e Embase. A busca foi estruturada utilizando os unitermos correspondentes a Coronavirus Disease 2019, isolamento social e alimentação. Todas as etapas foram executadas de forma independente por três revisores. Foram incluídos 12 estudos, totalizando 20.789 pessoas pesquisadas, com a predominância de estudos de corte transversal na população adulta. Os estudos analisados foram desenvolvidos na Itália $(n=4)$, Espanha $(n=2)$, Polônia $(n=1)$, China $(n=1)$, Índia ( $n=1)$, Estados Unidos da América $(n=1)$, África do Sul $(n=1)$ e multicêntrico continental $(n=1)$. A análise dos estudos incluídos evidenciou que a maioria das pessoas relatou não mudar a dieta habitual, observando-se também o aumento do hábito de cozinhar, consumir frutas, legumes e verduras e a diminuição do consumo de bebidas alcoólicas. Constatou-se diminuição do consumo de peixes e aumento das chamadas comfort foods. Verificou-se que a alimentação sofreu alterações em tempos de isolamento social. Sugerimos que novas pesquisas sejam realizadas em diferentes contextos socioeconômicos e demográficos. Propomos a continuidade do estudo desta temática, com realização de revisão sistemática com ou sem metanálise.

Palavras-chave: Infecções por coronavírus. Alimentos, dieta e nutrição. Revisão. Isolamento social.

\section{NTRODUCTION}

In March 2020, Coronavirus disease 2019 (Covid-19), an infectious disease caused by the Acute Severe Respiratory Syndrome 2 (SARS-CoV-2) virus, was characterized by the World Health Organization (WHO) as a pandemic [1,2]. According to WHO data, until August 2, 2020, 17,660,523 million cases of the disease had been confirmed worldwide, and in Brazil, these numbers represented on that date 2,662,485 million cases, with 92,475 thousand deaths [3].

Due to the exponential increase of cases and the absence of measures to immunize the population, non-pharmacological interventions, such as Social Isolation (SI), are indicated to mitigate the transmission of the disease virus. The main objective of social isolation is to contain the virus spread among populations, countries and continents and, to postpone the peak of the epidemic curve, thus reducing the demand for health care and the overload of these services [4]. However, the SI can have an impact on the physical and mental health of individuals and promote changes in life habits related to the practice of physical activity and eating [5]. Food choices may be compromised, mainly due to limited access to food shopping places, which can lead to reduced consumption of fresh food, especially fruits, vegetables and fish, to the detriment of ready-to-eat and ultra-processed foods [6]. In addition, emotional factors in response to routine changes and due to the disease itself, can increase the demand for foods rich in sugars or increase the desire for food [7]. Thus, the objective of this narrative review was to investigate the impact of SI on people's eating habits during the Covid-19 pandemic.

\section{METHODS}

Narrative review with systematic survey for studies published from January 1, 2019 to June 18, 2020 in the PubMed, Web of Science and Embase databases using uniterms and with the help of Boolean operators, according to Chart 1, without using filters. 
Chart 1 - Systematic search strategy used in the narrative review. Florianópolis (SC), Brazil, 2020.

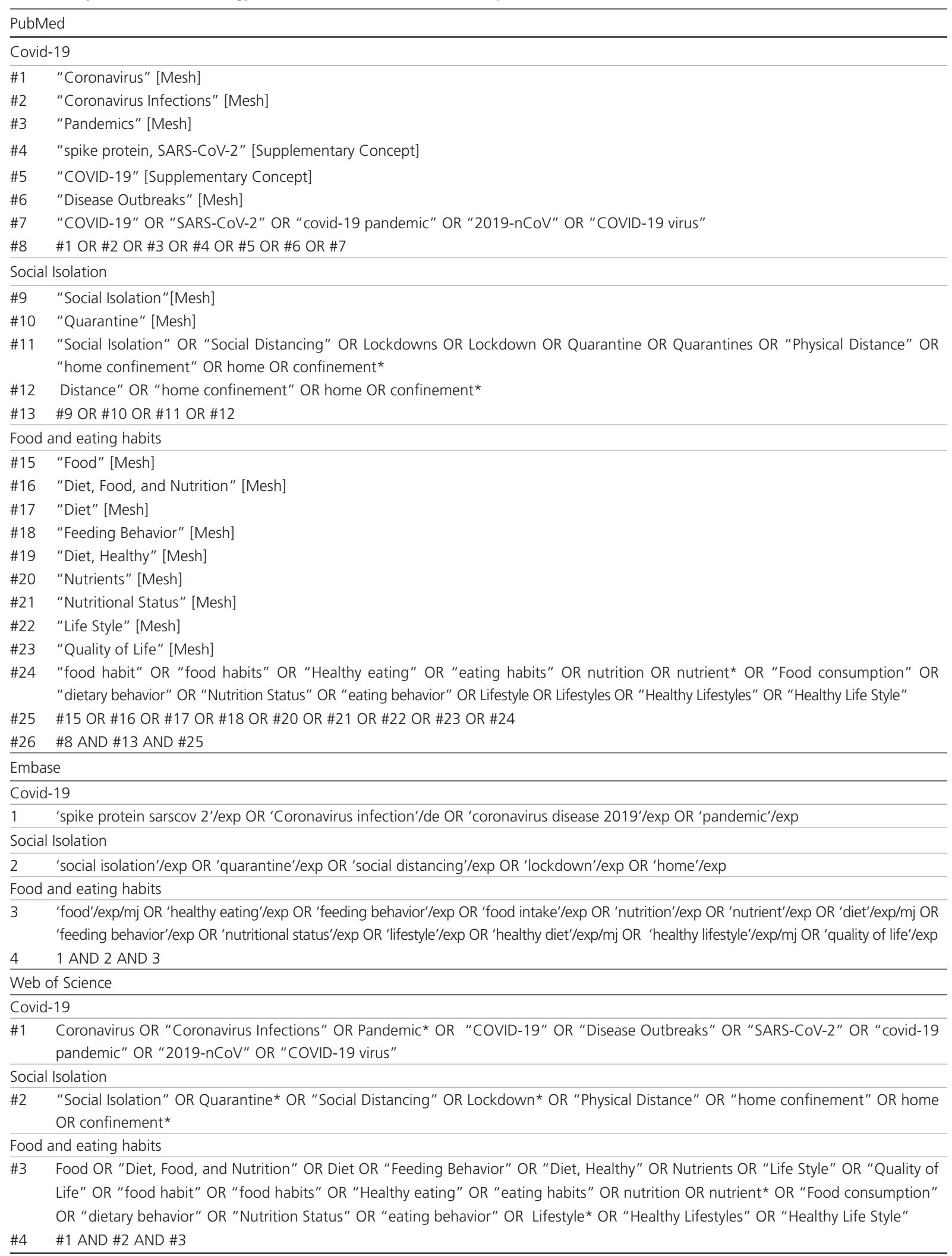

Note: 2019-nCoV: Novel Coronavirus 2019; Covid-19: Corona Virus Disease 2019; Exp: Exploded; MeSH: Medical Subject Headings; Mj: Major Focus; SARS-Cov-2: Severe Acute Respiratory Syndrome Coronavirus 2. 
The studies captured were transferred to the reference manager Mendeley ${ }^{\circledR}$ to remove duplicates and selected in the Rayyan ${ }^{\circledR}$ program in two stages: reading titles and abstracts and reading the full text. In the selection, the eligibility criteria were used: data collection performed during the isolation period by Covid-19 and that evaluated food and/or eating habits. Review and recommendation studies were excluded.

Data extraction was performed in the Microsoft Excel ${ }^{\circledR} 2010$ program using a standardized and tested form considering the following variables: authors, year and place of study; methodological design; sample characteristics (gender and age); method used for recruiting the sample; methodology used for data collection (such as online platform, telephone interview); instrument to assess diet; data collection period; type of measure adopted by the country to contain Covid-19 (such as SI); and main results related to food. For the collection, analysis and synthesis of the results related to food in the framework of social isolation, the following aspects were considered: quantity consumed, quality (referring to types of food and/ or nutrients consumed), number of meals, cooking habits, forms of preparation, forms of acquisition and food availability.

All steps were carried out independently by three of the authors and compared to verify agreement between them. In the case of any divergence, a fourth reviewer was consulted for final decision.

\section{RE S U L T S}

A total of 439 studies were identified. Out of these, 85 studies were excluded because they were duplicates. A total of 354 were reviewed by title and summary and 21 studies were read in full for eligibility. Twelve studies were included in the narrative review. The selection process is shown in Figure 1.

The Table 1 presents the main characteristics of the studies assessed. Seven studies were carried out on the European continent, four in Italy, two in Spain and one in Poland [8-14]. Two studies were carried out on the Asian continent, one in China and one in India $[15,16]$. One study was carried out in the American continent, in the United States of America and another in the African continent (South Africa) [17,18]. And only one study corresponded to a multinational survey, involving Europe, North Africa, West Asia and the Americas [19].

Cross-sectional studies were predominant $(n=11)$ and there was only one longitudinal survey [10]. All studies were carried out with populations of both genders; the majority included individuals over 18 years of age [12-15,17-19], two assessed specific populations such as athletes and individuals with diabetes and the longitudinal research assessed obese children and adolescents $[10,16,18]$. The sample sizes ranged from 41 to 7,514, totaling 20,789 people assessed in the 12 studies. Nine studies presented the type of measure established in the country for the containment of Covid-19, all of which described SI as a condition in which leaving home would occur only for essential purposes.

Data collections were carried out using questionnaires administered on online platforms, with a predominance of Google forms ${ }^{\circledR}$. To collect data on food, two studies used previously validated questionnaires on frequency and eating behavior and Adherence to the Mediterranean Diet $[8,12,13]$. The others used adapted instruments or not validated.

In the results related to food, the studies reviewed were grouped into three categories: (a) those that evaluated only eating changes during the SI period compared to the previous period $[9,10,12,17-19]$; (b) those which evaluated food intake only in the SI period [16]; and (c) those which assessed both $[8,11,13-15]$. 


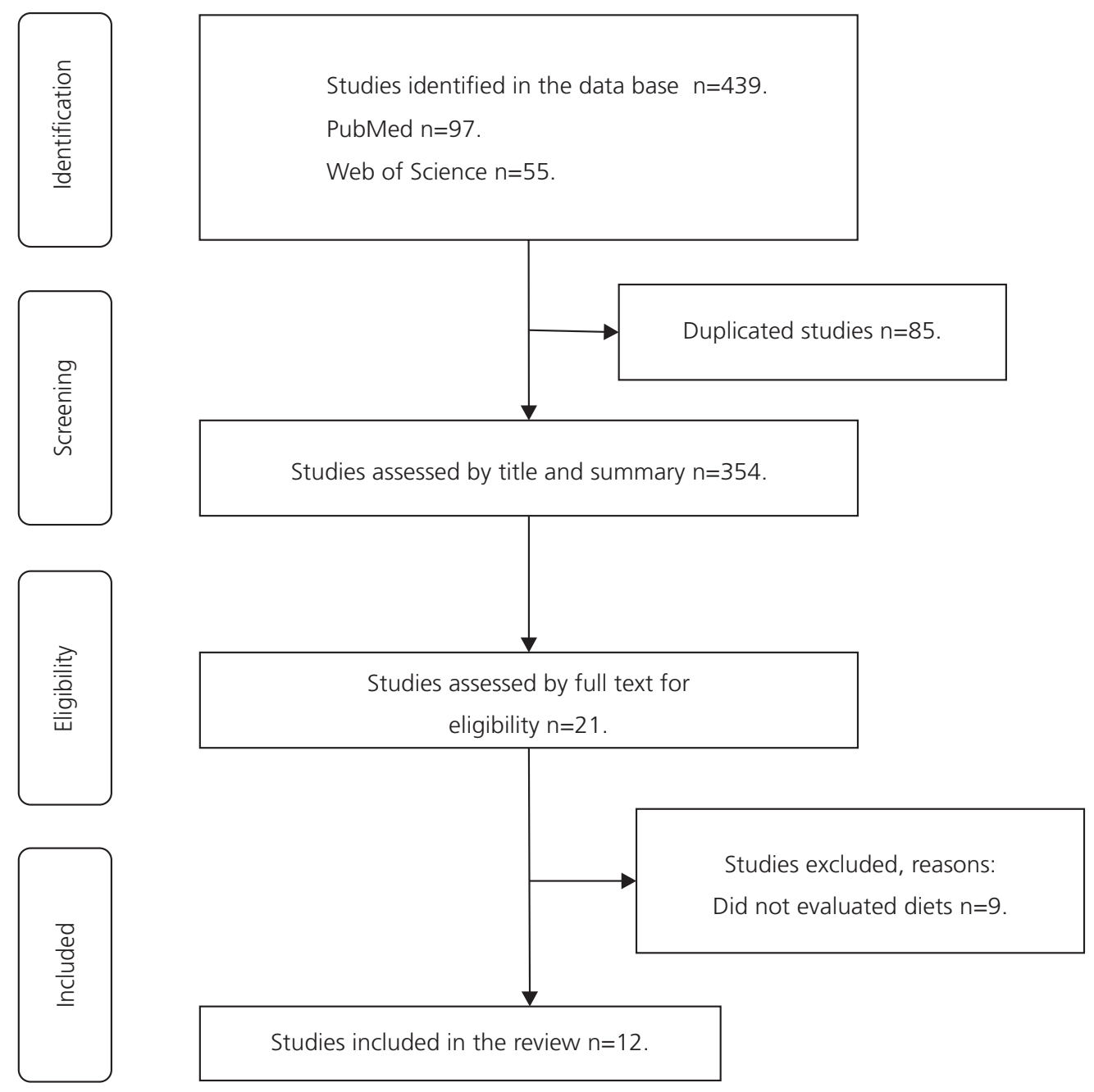

Figure 1 - Flowchart for selecting the 12 studies included in the narrative review.

Regarding changes in food eating during the SI shown in Table 2, the following changes were observed in the aspects: amount of food eaten $[11,12,14,17,19]$; number of meals $[8,10,17,19]$; cooking habits [8,12,14]; preparation methods [12]; acquisition [8]; food availability [11,12]; general quality of food $[9,18]$; and eating-related behaviors [17]. With the exception of Gallè et al. [9], Nachimuthu et al. [16], and Zachary et al. [17], all other studies analyzed the change in the consumption of specific drinks and foods, such as sugary drinks, vegetables, fruits, fish and sweets

The proportion of people who reported an increase in the amount of food eaten during SI ranged between $36.3 \%$ and $52.9 \%[11,12,14,17]$. One study identified an increase in the mean score of eating out of control (1.80 \pm 0.02 to $2.04 \pm 0.03)$ [19].

In the analysis of the number of meals, it is observed that during quarantine, three and four main meals per day (30.3\% and $39.3 \%$, respectively) and one and two daily snacks ( $28.3 \%$ and $36,1 \%$ respectively) were more prevalent [14]. In addition, $65.0 \%$ reported having breakfast daily during the pandemic [14]. In the Ammar et al. [19] multicentric study and in the study with obese children and adolescents by Pietrobelli et al. [10] there was an increase in the number of meals and snacks throughout the day. Zachary et al. [17] observed that in $11.5 \%, 22.0 \%$ and $38.7 \%$ of the participants there was an increase in food intake at breakfast, lunch and dinner meals, respectively. 
Table 1 - General characteristics of the 12 studies included in the narrative review. Florianópolis (SC), Brazil, 2020.

\begin{tabular}{|c|c|c|c|c|c|c|c|}
\hline & & & Variables & & & & \\
\hline Author & Country & Design & Population & Gender & Age & $\begin{array}{l}\text { Data collection } \\
\text { method }\end{array}$ & Period \\
\hline Di Renzo et al. [8]. & Italy & Cross-sectional & $\begin{array}{c}n=3,533 \\
(\geq 12 \text { years of } \\
\text { age })\end{array}$ & $\begin{array}{l}\text { M: } 23.9 \% \\
F: 76.1 \%\end{array}$ & $\begin{array}{c}18-65 \text { years of age: } \\
91.5 \%\end{array}$ & Google Forms & $\begin{array}{c}\text { April 5-24, } \\
2020\end{array}$ \\
\hline
\end{tabular}

Food evaluation

(a) PREDIMED Mediterranean Diet Adherence Screener; (b) Questions about changes in the consumption of specific foods and/or drinks; (c) Questions about the frequency of consumption of specific foods and/or drinks; (d) Questions about meals (number and/or frequency); (e) Questions about food purchase; (f) Perception of diet change.

Conclusion

Greater adherence to the MD in the population between 18 and 30 years of age when compared to the younger and older population. Perception of weight gain was observed in $48.6 \%$ of the population, while a slight increase in physical activity has been reported in $38.3 \%$ of respondents. In addition, $15.0 \%$ of respondents turned to farmers or organic purchasing groups for fruits and vegetables, especially in Northern and Central Italy, where BMI values were lower.

\begin{tabular}{|c|c|c|c|c|c|c|c|}
\hline Author & Country & Design & Population & Gender & Age & $\begin{array}{c}\text { Data collection } \\
\text { method }\end{array}$ & Period \\
\hline Gallè et al. [9] & Italy & Cross-sectional & $\begin{array}{c}\mathrm{n}=2,125 \\
\text { (undergraduates) }\end{array}$ & $\begin{array}{c}\text { M: } 37.2 \% \\
F: 62.8 \%\end{array}$ & Middle age: 22.5 & $\begin{array}{c}\text { Online } \\
\text { questionnaire }\end{array}$ & $\begin{array}{c}\text { Last } 2 \\
\text { weeks of } \\
\text { March } \\
2020\end{array}$ \\
\hline
\end{tabular}

Food evaluation

(a) Perception of diet change

Conclusion

Social isolation did not change the diet and smoking habits, but it did cause a decrease in the level of physical activity. Preventive interventions should also turn restrictive measures into an opportunity to improve lifestyle

\begin{tabular}{|c|c|c|c|c|c|c|c|}
\hline Author & Country & Design & Population & Gender & Age & $\begin{array}{c}\text { Data collection } \\
\text { method }\end{array}$ & Period \\
\hline \multirow{7}{*}{$\begin{array}{l}\text { Pietrobelli et al. } \\
{[10]}\end{array}$} & \multirow[t]{7}{*}{ Italy } & \multirow[t]{7}{*}{ Longitudinal } & \multirow{7}{*}{$\begin{array}{c}\mathrm{n}=41 \\
\text { (obese children } \\
\text { and adolescents) }\end{array}$} & \multirow{7}{*}{$\begin{array}{l}\text { M: } 53.7 \% \\
F: 46.3 \%\end{array}$} & \multirow[t]{7}{*}{$6-18$ years of age } & Baseline: & Baseline: \\
\hline & & & & & & Personal & May 13 \\
\hline & & & & & & interview & $\begin{array}{c}\text { to July } 30, \\
2019\end{array}$ \\
\hline & & & & & & \multirow{4}{*}{$\begin{array}{l}\text { Lockdown: } \\
\text { Telephone } \\
\text { interview }\end{array}$} & Lockdown: \\
\hline & & & & & & & March \\
\hline & & & & & & & 10 to \\
\hline & & & & & & & April 2020 \\
\hline
\end{tabular}

Food evaluation

(a) Questions about changes in the consumption of specific foods and/or drinks; (b) Questions about meals (number and/or frequency).

Conclusion

In children and adolescents, social isolation seems to create an unfavorable environment for the maintenance of healthy lifestyle behaviors. Depending on the duration, the undesirable effects of social isolation can have a lasting impact on the level of adiposity.

\begin{tabular}{|c|c|c|c|c|c|c|c|}
\hline Author & Country & Design & Population & Gender & Age & $\begin{array}{c}\text { Data collection } \\
\text { method and }\end{array}$ & Period \\
\hline Scarmozzino e & Italy & Cross-sectional & $n=1,929$ & M: $67.0 \%$ & $21-65$ years of age & Google Forms & April 3-15, \\
\hline Visioli [11] & & & & F: $32.9 \%$ & $84.1 \%$ & & 2020 \\
\hline
\end{tabular}

Food evaluation

(a) Questions about frequency of consumption of specific foods and beverages; (b) Questions about changes in the consumption of specific foods and/or drinks.

Conclusion

Almost half (49.6\%) of the respondents did not change their diet; however, $46.1 \%$ of them reported that they were eating more. There was an increase in the consumption of "comfort foods", mainly chocolate, ice cream and desserts (42.5\%) and snacks (23.5\%). $21.2 \%$ of respondents increased their consumption of fresh fruits and vegetables. Purchases of ready meals reduced by almost $50 \%$. 
Table 1 - General characteristics of the 12 studies included in the narrative review. Florianópolis (SC), Brazil, 2020.

Variables

\begin{tabular}{|c|c|c|c|c|c|c|c|}
\hline Author & Country & Design & Population & Gender & Age & $\begin{array}{l}\text { Data collection } \\
\text { method }\end{array}$ & Period \\
\hline $\begin{array}{l}\text { Rodríguez-Pérez et } \\
\text { al. [12] }\end{array}$ & Spain & Cross-sectional & $\begin{array}{c}\mathrm{n}=7,514 \\
(>18 \text { years of } \\
\text { age })\end{array}$ & $\begin{array}{l}\text { M: } 29.3 \% \\
F: 70.6 \%\end{array}$ & $\begin{array}{c}21-65 \text { years of age: } \\
91.3 \%\end{array}$ & Google Forms & $\begin{array}{c}\text { March } \\
2020 \\
\text { (during } 3 \\
\text { weeks) }\end{array}$ \\
\hline
\end{tabular}

Food evaluation

(a) PREDIMED Mediterranean diet Adherence Screener (validated); (b) Questions about changes in eating and/or cooking habits; (c) Questions about changes in consumption of specific foods and beverages.

Conclusion

Improvement in eating behaviors was observed during social isolation, reflected by greater adherence to MedDiet. Health-related food choices included greater intake of fruits, vegetables or legumes, and less consumption of red meat, alcohol, fried foods or sweets compared to usual habits.

\begin{tabular}{lcccccc}
\hline Author & Country & Design & Population & Gender & Age & $\begin{array}{c}\text { Data collection } \\
\text { method }\end{array}$ \\
\hline $\begin{array}{l}\text { Romeo-Arroyo } \\
\text { et al. [13] }\end{array}$ & Spain & Cross-sectional & $\mathrm{n}=600(\mathrm{NI})$ & F: $50.1 \%$ & 18-68 years of age & $\begin{array}{c}\text { Online survey; } \\
\text { Food evaluation }\end{array}$ \\
Food week \\
of April
\end{tabular}

(a) Food Groups Consumption Frequency Questionnaire (QFCGA) (validated); (b) Dutch Eating Behavior Questionnaire, Spanish version (validated); (c) Questions about eating and cooking habits; (d) Questions about changes in the consumption of specific foods and/or drinks; (e) List of new habits acquired.

Conclusion

Different attitudes were present in Spanish homes, some of them related to low emotional status and possible less healthy eating habits, and others focused on trying to maintain healthier habits.

\begin{tabular}{|c|c|c|c|c|c|c|c|}
\hline Author & Country & Design & Population & Gender & Age & $\begin{array}{l}\text { Data collection } \\
\text { method }\end{array}$ & Period \\
\hline $\begin{array}{l}\text { Sidor and Rzymski } \\
\text { [14] }\end{array}$ & Poland & Cross-sectional & $\begin{array}{c}n=1,097 \\
(\geq 18 \text { years of } \\
\text { age })\end{array}$ & $\begin{array}{l}\text { M: } 4.9 \% \\
\text { F: } 95.1 \%\end{array}$ & $\begin{array}{c}18-25 \text { years of age: } \\
53.6 \%\end{array}$ & Online survey & $\begin{array}{c}\text { April 17/ } \\
\text { May 1, } \\
2020\end{array}$ \\
\hline
\end{tabular}

Food evaluation

(a) Questions about changes in eating and/or cooking habits; (b) Questions about the frequency of consumption of specific foods and/or drinks; (c) Questions about meals (number and/or frequency); (d) Level of concern of contracting SARS-CoV-2 during shopping or contact with food. Conclusion

Social isolation can affect eating habits and behaviors (eating more, more snacks, increased alcohol consumption (Poland) and weight change). Overweight and obese individuals were more prone to these changes (frequency of consumption: <vegetables, fruits and legumes and >salty foods, meat and dairy products).

\begin{tabular}{|c|c|c|c|c|c|c|c|}
\hline Author & Country & Design & Population & Gender & Age & $\begin{array}{c}\text { Data collection } \\
\text { method }\end{array}$ & Period \\
\hline Zhao et al. [15] & China & Cross-sectional & $\begin{array}{c}n=1,938(18-80 \\
\text { years of age })\end{array}$ & $\begin{array}{c}\mathrm{M}: 34.3 \% ; \mathrm{F}: \\
65.7 \%\end{array}$ & $\begin{array}{c}18-45 \text { years of age: } \\
83.6 \%\end{array}$ & Wenjuanxing & March 2020 \\
\hline
\end{tabular}

Food evaluation

(a) Family Diet Diversity Index; (b) Questions about food purchase; (c) Questions about consumption of specific foods in the last 24 hours; (d) Questions about specific eating behaviors to deal with Covid-19.

Conclusion

Good general food diversity. Less food diversity in areas with a high number of Covid-19 confirmed cases. Eating behaviors to deal with Covid-19 (consumption of vitamin C, probiotics, other dietary supplements, alcohol and vinegar) were associated with greater diversity. The main ways of obtaining food were internal storage and personal purchases.

\begin{tabular}{|c|c|c|c|c|c|c|c|}
\hline Author & Country & Design & Population & Gender & Age & $\begin{array}{l}\text { Data collection } \\
\text { method }\end{array}$ & Period \\
\hline $\begin{array}{l}\text { Nachimithu et al. } \\
{[16]}\end{array}$ & India & Cross-sectional & $\begin{array}{c}n=100 \text { individuals } \\
\text { with diabetes }\end{array}$ & $\begin{array}{l}\text { M: } 54 \\
\text { F: } 46\end{array}$ & $\geq 18-64: 57.0 \%$ & Survey Monkey & $\begin{array}{c}\text { April 1-15 } \\
2020\end{array}$ \\
\hline
\end{tabular}

Food evaluation

(a) Question about diet and exercise during lockdown 
Table 1 - General characteristics of the 12 studies included in the narrative review. Florianópolis (SC), Brazil, 2020.

Conclusion

Most people investigated reported that they were able to maintain food care as well as being more physically active at home during social isolation.

\begin{tabular}{|c|c|c|c|c|c|c|c|}
\hline Author & Country & Design & Population & Gender & Age & $\begin{array}{c}\text { Data collection } \\
\text { method }\end{array}$ & Period \\
\hline Zachary et al. [17] & $\begin{array}{l}\text { United } \\
\text { States }\end{array}$ & Cross-sectional & $\begin{array}{c}n=173 \\
(>18 \text { years of } \\
\text { age })\end{array}$ & $\begin{array}{l}M: 44.5 \% \\
F: 55.5 \%\end{array}$ & Average age: 28.1 & Survey Monkey & $\mathrm{NI}$ \\
\hline
\end{tabular}

Food evaluation

Weight and Lifestyle Inventory

Conclusion

Approximately $22 \%$ of the sample reported weight gain during social isolation. The risk factors were inadequate sleep, snacks after dinner, lack of food restriction, food in response to stress and reduced physical activity.

\begin{tabular}{|c|c|c|c|c|c|c|c|}
\hline Author & Country & Design & Population & Gender & Age & $\begin{array}{c}\text { Data collection } \\
\text { method }\end{array}$ & Period \\
\hline Pillay et al. [18] & South Africa & Cross-sectional & $\mathrm{n}=692$ (athletes) & $\begin{array}{l}M: 67.0 \% \\
F: 33.0 \%\end{array}$ & $\mathrm{NI}$ & Google Forms & $\begin{array}{c}\text { April } \\
28-30 \\
2020\end{array}$ \\
\hline
\end{tabular}

Food evaluation

(a) Perception of diet change; (b) Questions about specific eating behaviors to deal with Covid-19.

Conclusion

Covid-19 has significant physical and mental effects on athletes, including worsening of nutrition. Medical, nutritional and psychological support is recommended during and after social isolation.

\begin{tabular}{|c|c|c|c|c|c|c|c|}
\hline Author & Country & Design & Population & Gender & Age & $\begin{array}{l}\text { Data collection } \\
\text { method }\end{array}$ & Period \\
\hline Ammar et al. [19] & $\begin{array}{c}\text { Europe, } \\
\text { Africa, Asia } \\
\text { and the } \\
\text { Americas }\end{array}$ & Cross-sectional & $\begin{array}{c}n=1,047 \\
(\geq 18 \text { years of } \\
\text { age })\end{array}$ & $\begin{array}{c}\text { M: } 46.2 \% \\
\text { F: } 53.8 \%\end{array}$ & $\begin{array}{c}18-35 \text { years of age: } \\
55.1 \%\end{array}$ & Google Forms & $\begin{array}{c}\text { April 6-11, } \\
2020\end{array}$ \\
\hline
\end{tabular}

Food evaluation

Short Diet Behaviors Questionnaire for Lockdowns

Conclusion

Interim results of the investigation indicate a negative effect of home confinement on physical activity and diet behavior with a significant increase in sitting time and an unhealthy diet, indicative of a more sedentary lifestyle.

Note: BMI: Body Mass Index; Covid-19: Corona Virus Disease 2019; F: Female; M: Male; MD: Mediterranean Diet; MedDiet: Mediterranean Diet; NI: Not Informed; Covid-19: Coronavirus Disease 2019; PREDIMED: PREvención con Dleta MEDiterránea; SARS-Cov-2: Severe Acute Respiratory Syndrome Coronavirus 2.

In two studies, significant increases in cooking habits were observed, reported by $45.7 \%$ and $62.3 \%$ of those investigated $[11,12]$. The preparation of homemade recipes was more present in the food routine during isolation, just as there was a decrease in the proportion of participants who reported the consumption of fried foods and a decrease in the proportion of food delivery services use [8]. The most frequently used form of food purchase was supermarket shopping $[8,17]$.

The difficulty in finding food was reported by $27.0 \%$ of the sample in the Rodríguez-Pérez et al. study [12]. This aspect negatively influenced consumption of fruits and vegetables, as, according to the study by Scarmozzino and Visioli [11], 33.5\% of people reported reducing their consumption due to the difficulty in finding them. This aspect has also been reported as a reason for dietary changes [11]. 
Table 2 - Changes in eating habits due to social isolation observed in the 12 studies included in the narrative review. Florianópolis (SC), Brazil, 2020 .

\begin{tabular}{|c|c|c|c|c|}
\hline \multirow{2}{*}{ Aspects assessed } & \multicolumn{4}{|c|}{ Variables } \\
\hline & $\leftrightharpoons \%$ & $\uparrow \%$ & $\downarrow \%$ & Score \\
\hline \multicolumn{5}{|l|}{ Quantity of food intake } \\
\hline Scarmozzino and Visioli et al. [11] & 47.1 & 52.9 & - & - \\
\hline Rodríguez-Pérez et al. [12] & 63.7 & 36.3 & - & - \\
\hline Sidor and Rzymski et al. [14] & - & 43.5 & - & - \\
\hline Zachary et al. [17] & 61.3 & 38.7 & - & - \\
\hline Ammar et al. [19] & - & - & - & $\uparrow$ \\
\hline \multicolumn{5}{|l|}{ Number of daily meals } \\
\hline Di Renzo et al. [8] & 57.8 & 23.5 & 17.5 & - \\
\hline Pietrobelli et al. [10] & - & - & - & $\uparrow$ \\
\hline Zachary et al. [17] & 34.7 & 65.3 & - & - \\
\hline Ammar et al. [19] & - & - & - & $\uparrow$ \\
\hline \multicolumn{5}{|l|}{ Cooking } \\
\hline Di Renzo et al. [8] & - & $\uparrow$ & - & - \\
\hline Rodríguez-Pérez et al. [12] & 50.7 & 45.7 & 3.6 & - \\
\hline Sidor and Rzymski et al. [14 & - & 62.3 & - & - \\
\hline \multicolumn{5}{|l|}{ Preparation (frying) } \\
\hline Rodríguez-Pérez et al. [12] & 73.4 & 6.3 & 20.3 & - \\
\hline \multicolumn{5}{|l|}{ Acquisition (food delivery) } \\
\hline Di Renzo et al. [8] & - & - & $\downarrow$ & - \\
\hline \multicolumn{5}{|l|}{ Food availability } \\
\hline Scarmozzino and Visioli et al. [11] & - & - & 33.5 & - \\
\hline Rodríguez-Pérez et al. [12] & - & - & 27.0 & - \\
\hline \multicolumn{5}{|l|}{ Food quality } \\
\hline Gallè et al. [9] & 41.9 & 41.0 & 17.1 & - \\
\hline Pillay et al. [18] & - & 53.0 & 47.0 & - \\
\hline
\end{tabular}

Note: $\leftrightharpoons$ Maintenance; $\uparrow$ Increase; $\downarrow$ Decrease.

In assessing the general quality of the diet, Gallè et al. [9] and Pillay et al. [18] found improvement in $41.0 \%$ and $53.0 \%$ of the population, respectively. The quality deterioration was reported by $17.1 \%$ and $47.0 \%$, respectively $[9,18]$. In the study by Nachimuthu et al. [16], which included people with diabetes mellitus, $80 \%$ reported being regularly following a diet and workout routine during SI and $19.0 \%$ reported difficulty due to lack of resources [16].

Zachary et al. [17] evaluated behaviors related to the stimulus for food. The authors identified that the behaviors reported in the greatest proportion were the desire to eat certain foods (73\%) and boredom (73\%), followed by stimulation in response to sight and smell (65\%), after dinner (65\%), eating with friends and family (59\%) and in response to stress (52.0\%.

The use of food supplements as a behavior related to Covid-19 was mentioned in two studies $[15,18]$. Pillay et al. [18] found that $32.0 \%$ of the athletes evaluated reported using supplements during this period to improve immunity. Among these individuals, 36.0\% reported the use of multivitamins, 36.0\% vitamin C, $15.0 \%$ protein, $4.0 \%$ zinc, $23.0 \%$ reported other supplements and $5 \%$ provided no information [18]. In the study by Zhao et al. [15], 37.7\% of the interviewees reported making intentional use of dietary supplements, Chinese herbs or specific foods due to Covid-19, including vitamin $C(18.2 \%)$, probiotics (11.7\%), other food supplements (8.0\%) and Chinese herbs (9.6\%). A few studies have also assessed the change in intake of specific food and beverage groups $[8,10-15,18,19]$, presented in Table 3. 
Table 3 - Changes in eating habits due to social isolation observed in the 12 studies included in the narrative review. Florianópolis (SC), Brazil, 2020.

\begin{tabular}{|c|c|c|c|}
\hline \multirow{2}{*}{ Aspects assessed } & \multicolumn{3}{|c|}{ Variables } \\
\hline & $\leftrightharpoons \%$ & $\uparrow \%$ & $\downarrow \%$ \\
\hline \multicolumn{4}{|l|}{ Fruits and vegetables } \\
\hline Di Renzo et al. [8] & - & 37.4 & 35.8 \\
\hline Scarmozzino and Visioli et al. [11] & 69.2 & 21.2 & 8.7 \\
\hline Romeo-Arroyo et al. [13] & - & $>30.0$ & - \\
\hline \multicolumn{4}{|l|}{ Fruits and vegetables (canned) } \\
\hline Scarmozzino and Visioli et al. [11] & - & 0.9 & - \\
\hline \multicolumn{4}{|l|}{ Fish $^{1}$} \\
\hline Di Renzo et al. [8] & - & - & - \\
\hline Scarmozzino and Visioli et al. [11] & 64.8 & 8.5 & 13.7 \\
\hline Romeo-Arroyo et al. [13] & - & - & $>33.0$ \\
\hline \multicolumn{4}{|l|}{ Meat } \\
\hline Pietrobelli et al. [10] & - & - & $\uparrow$ \\
\hline Scarmozzino and Visioli et al. [11] & 75.1 & 4.0 & $14.9^{2}$ \\
\hline Romeo-Arroyo et al. [13] & - & $>20.0$ & - \\
\hline \multicolumn{4}{|l|}{ Processed Meat } \\
\hline Scarmozzino and Visioli et al. [11] & - & 6.0 & - \\
\hline \multicolumn{4}{|l|}{ Milk/yogurt } \\
\hline Scarmozzino and Visioli et al. [11] & 76.3 & 14.3 & 9.4 \\
\hline \multicolumn{4}{|l|}{ Cheese } \\
\hline Scarmozzino and Visioli et al. [11] & 79.1 & 13.3 & 7.6 \\
\hline \multicolumn{4}{|l|}{ Pasta } \\
\hline Romeo-Arroyo et al. [13] & - & $\sim 40.0$ & - \\
\hline \multicolumn{4}{|l|}{ Olive oil } \\
\hline Scarmozzino and Visioli et al. [11] & 93.2 & 5.0 & 1.8 \\
\hline \multicolumn{4}{|l|}{ Snacks } \\
\hline Scarmozzino and Visioli et al. [11] & 57.6 & 23.5 & 18.9 \\
\hline Rodríguez-Pérez et al. [12] & 46.7 & 37.6 & 15.7 \\
\hline \multicolumn{4}{|l|}{ Fast-food } \\
\hline Rodríguez-Pérez et al. [12] & 60.0 & 5.1 & 34.9 \\
\hline \multicolumn{4}{|l|}{ Ready meals } \\
\hline Scarmozzino and Visioli et al. [11] & 47.4 & 3.1 & 49.5 \\
\hline \multicolumn{4}{|l|}{ Junk food } \\
\hline Di Renzo et al. [8] & - & 25.6 & 29.8 \\
\hline Ammar et al. [19] & - & $\uparrow$ & - \\
\hline \multicolumn{4}{|l|}{ Potato chips } \\
\hline Pietrobelli et al. [10] & & $\uparrow$ & \\
\hline \multicolumn{4}{|l|}{ Crackers } \\
\hline Scarmozzino and Visioli et al. [11] & 66.1 & 19.1 & 14.8 \\
\hline \multicolumn{4}{|l|}{ Sweets } \\
\hline Di Renzo et al. [8] & - & - & $\downarrow$ \\
\hline Scarmozzino and Visioli et al. [11] & 44.0 & 42.5 & 13.5 \\
\hline Romeo-Arroyo et al. [13] & - & $>50.0$ & - \\
\hline Sugary Drinks & & & \\
\hline Pietrobelli et al. [10] & - & $\uparrow$ & - \\
\hline Scarmozzino and Visioli et al. [11] & 72.7 & 5.0 & 22.3 \\
\hline Coffee/tea/infusions & & & \\
\hline Di Renzo et al. [8] & - & $\uparrow$ & - \\
\hline Scarmozzino and Visioli et al. [11] & 58.7 & 29.8 & 11.5 \\
\hline Alcohol & & & \\
\hline Di Renzo et al. [8] & - & - & $\downarrow$ \\
\hline Scarmozzino and Visioli et al. [11] & 53.1 & 10.1 & 36.8 \\
\hline Rodríguez-Pérez et al. [12] & 32.3 & 10.4 & 57.3 \\
\hline Romeo-Arroyo et al. [13] & - & $>20.0$ & - \\
\hline Sidor and Rzymski et al. [14] & 77.0 & 14.6 & - \\
\hline Zhao et al. [15] & - & 10.6 & - \\
\hline Pillay et al. [18] & - & 10.0 & - \\
\hline Ammar et al. [19] & - & - & $\downarrow$ \\
\hline
\end{tabular}

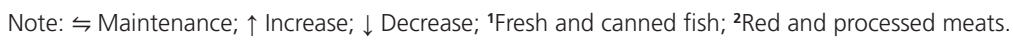


The consumption of alcoholic beverages was assessed in eight studies $[8,11-15,18,19]$. RodriguezPérez et al. [12] found a predominance in the decrease and maintenance of alcohol consumption, reported by $57.3 \%$ and $32.3 \%$ of the sample, respectively. Ammar et al. [19] also observed a reduction in the mean alcohol binge score $(1.15 \pm 0.01$ to $1.08 \pm 0.01)$ [19]. On the other hand, in the studies by Scarmozzino and Visioli [11] and Sidor and Rzymski [14], there was a higher proportion of reports indicating maintenance of the usual consumption of alcoholic beverages during the isolation period, representing $53.1 \%$ and $77.0 \%$ of the samples evaluated, respectively.

The study by Scarmozzino and Visioli [11] found that the majority of the population maintained the usual consumption of sugary drinks (juices, soft drinks, tonic, etc.) $(72.7 \%)$, with $79.8 \%$ of people consuming less than once a week [11]. In contrast, in Pietrobelli et al. [10], the longitudinal analysis with children and adolescents identified an increase in the average daily frequency of consumption during the SI $(0.90 \pm 1.16)$ when compared to the previous period $(0.40 \pm 0.90)$ [10]. Pillay et al. [18] mentioned that among the athletes who reported worsening of the diet during the SI (53\% of the total sample), 30.0\% reported to be due to the consumption of carbonated drinks. The increase in the consumption of hot drinks (coffee, tea and infusions) was reported by more than $20 \%$ of the individuals studied by Di Renzo et al. [8] and was also mentioned by $29.8 \%$ of the population in the study by Scarmozzino and Visioli [11].

Maintaining the consumption of pasta, rice, bread and cereals was mentioned by more than $50 \%$ of the individuals in the studies by Romeo-Arroyo et al. [13]. In contrast, Di Renzo et al. [8] observed that 20\% of the study population increased cereal consumption.

Most individuals maintained their consumption of legumes according to the study by Romeo-Arroyo et al. [13], but there was an increase in legumes consumption by more than $10 \%$ of the study individuals, according to Di Renzo et al. [8]. The prevalence of daily consumption of legumes was $70.1 \%$ according to Zhao et al. [15]. Although it was found that the majority of individuals maintained their consumption of fruits and/or vegetables during $\mathrm{SI}$, it is highlighted that $21.2 \%$ and more than $30 \%$ of the population reported a consumption increase of these foods $[11,13]$.

Romeo-Arroyo, et al. [13] highlighted that the majority of individuals maintained the consumption of meat and eggs. However, Pietrobelli et al. [10] observed a significant increase $(p<0.05)$ in the average consumption of red meat in children and adolescents as compared to the previous period $(1.80 \pm 1.53$ servings/day) and during the SI (3.46 2.45 servings/day) [10]. Still, among those who mentioned worsening of the diet in the study by Pillay et al. [18], 15\% of the athletes reported that their response was on account of the excess consumption of red meat.

Di Renzo et al. [8] highlighted an increase in the consumption of white meat (not including fish) in more than $10 \%$ of people. A decrease in fish consumption was found in several studies: Di Renzo et al. [8] (reduction in more than $20 \%$ of individuals), Romeo-Arroyo et al. [13] (reduction in more than 33.0\% of the population) and Scarmozzino and Visioli [11]. In the latter, the authors found that $64.8 \%$ of individuals consumed fresh and canned fish as usual, $8.5 \%$ increased and $13.7 \%$ reduced consumption. In addition, $13.0 \%$ of people were consuming less fresh fish and more canned fish [11].

The change in the consumption of milk and dairy products and cheese was evaluated only by Scarmozzino and Visioli [11]. The population studied by them reported usual consumption for these food groups, representing $76.3 \%$ for reports of consumption of milk and dairy products and $19.1 \%$ for cheese consumption. [11].

Snacks and fast foods showed consumption similar to the period before social isolation, representing $46.7 \%$ and $57,6 \%$ for snacks, and $60 \%$ for fast-foods [11,12]. Additionally, Scarmozzino and Visioli [11] 
evaluated the change in the consumption of ready meals and found a higher proportion of reports of maintenance or decrease in consumption, with values of $47.4 \%$ and $49.5 \%$, respectively.

In the longitudinal study by Pietrobelli et al. [10], children and adolescents reported a significant increase in the consumption of daily servings of potato chips with an average of $0.07 \pm 0.24$ to $0.61 \pm 0.83$. In the study by Ammar et al. [19] the average score of frequency of junk food consumption increased significantly during the SI, from $2.18 \pm 0.02$ to $2.27 \pm 0.03$. However, in the study by Di Renzo et al. [8] the proportion of increase and decrease reports on the consumption of these foods was similar in the evaluated population, representing $25.6 \%$ and $29.8 \%$, respectively.

Scarmozzino and Visioli [11] observed in the studied population a greater predominance of usual consumption of cookies (66.1\%). Usual consumption of sweets was reported in $44.0 \%$ and the authors observed an increase in $42.5 \%$ of the population for this food [11]. Romeo-Arroyo et al. [13] found similar values regarding the increase in the consumption of sweets in more than $50 \%$ of the individuals assessed.

\section{DISCUSSION}

This review included studies that investigated changes in consumption and/or eating habits in times of SI due to Covid-19. We found that in general people maintained the usual diet, although some studies have also found favorable and/or unfavorable changes in the diet.

As favorable changes in eating habits, we can highlight the increase in the habit of cooking and the decrease in the preparation of fried foods. Changes in these aspects may be related to the greater time availability for preparing meals. In a survey of university students $(n=350), 51 \%$ reported that time is an important factor to have a healthy diet, and having time to cook was referred to as being very (47\%) and extremely (29\%) important for this practice [20].

The increase in the consumption of fruits and vegetables, as well as the greater adherence to the Mediterranean diet, can be acknowledged as a positive change. This observation is in line with the publication of the WHO guidelines on food and nutrition for the isolation period. In this guide, WHO refers to fruits and vegetables as the best food to be consumed in the isolation period [21]. In addition, fruits and vegetables are sources of essential micronutrients for the immune system, mainly vitamins $A, C, D, E, B 2$, $B 6$ and B12, folic acid, iron, selenium and zinc [22]. Another nutrient that favors the immune function and has an anti-inflammatory characteristic is omega-3 fatty acid, found in fish [23]. However, in our study, we identified a decrease in the consumption of this food, which may suggest a difficulty in the ability to prepare this type of food or in the reduction of the purchase at specific places where fish is sold [24].

Among the diet changes considered negative for health, we can mention increase in the consumption of foods with high energy density, high concentration of sugar and fat (sweets, sugary drinks, snacks and sauces), also called comfort foods. The increase in consumption of these foods may be due to the increase in the levels of anxiety and stress and is related with negative health outcomes $[25,26]$.

The results observed in only one study with obese children and adolescents indicate unfavorable changes in the diet, such as an increase in the intake of sugary drinks and potato chips. The habitual consumption of these foods is associated with an increased risk of overweight and obesity [27]. It is noteworthy that the behaviors and habits acquired in this phase of life tend to be perpetuated in adult life, an aspect of great concern in a scenario of continuity of measures of social isolation for an indefinite period [28]. Thus, there is a need for further studies in this population to target interventions during this period. 
Although the aim of this review was not the search for articles that exclusively evaluated alcohol consumption during the pandemic, the studies included indicated greater proportions of reduction and maintenance of alcohol consumption. However, it is known that alcohol consumption during the pandemic can represent an important public health problem [29]. During social isolation related to Covid-19, individuals may experience greater anxiety and depressive symptoms and evidence suggests that psychological suffering related to Covid-19 is associated with increased alcohol consumption [30,31]. A study in Poland found that $17.4 \%$ of the sample reported a decrease in the consumption of alcoholic beverages due to the pandemic, $13.8 \%$ an increased consumption and about $41.1 \%$ did not report changes [32].

The decrease in alcohol consumption was observed concomitantly with the increase in the use of coffee/tea/infusions. One hypothesis is that staying at home without contact with other people has influenced the pattern of drink consumed, since alcoholic beverages are related to the socialization process, as a set of strategies that facilitate the coexistence between people, especially young people [33].

We observed that the use of dietary supplements was a strategy used during SI. Some authors and even social media professionals have recommended the use of supplements to enhance immunity [34,35]. Easy access to information may have favored the adoption of this behavior; however supplementation without the guidance of a trained professional is not advisable.

There was an increase in the number of meals among children and adolescents [10]. A study, carried out not in connection with the pandemic, with a population in the same age group, found that a greater number of meals at home may be associated with better quality of the diet and lower intake of saturated fat [36]. This behavior was also observed in studies with a predominantly adult sample $[8,17,19]$. However, in the SI situation, it is not possible to infer that the increase in the number of meals can be beneficial for the diet, since it can be associated with the consumption of foods considered comfort food [25].

Finally, we highlight that according to the studies included in this review, it is not possible to infer whether food changes differ between countries, since the studies present different recruitment methodologies and data collection on food consumption, as well as the variability of the groups and types of foods assessed. Still, the method of data collection (online questionnaire), necessary due to social isolation, can be an important factor of sample selection bias, including populations with higher education and income, as well as younger populations, depending on the availability and familiarity with digital technologies. Most of the studies found so far have occurred in countries with a high Human Development Index (HDI) $(n=8)$, with limited results in developing countries and no studies in low HDI countries. [37]. We emphasize that Low and Middle-Income (LMIC) countries can suffer an even greater (or different) impact in the isolation process.

The potentialities of this study include: the current and relevant subject when covering this pandemic period and the methodological rigor in the stages of search, selection and data extraction, according to the recommendations of Preferred Reporting Items for Systematic Reviews and Meta-Analysis (PRISMA). As limitations, there is the time limit considering the continuity of the pandemic.

We suggest that new studies be carried out in different countries, age groups and economic levels. The studies should also focus on the impact of diet changes in times of isolation on future outcomes, with follow-up studies. We emphasize the importance of developing and validating self-applicable online tools that can reach different population groups, thus providing valid data for assessing food consumption in similar periods in the future. Finally, we propose to continue the study of this topic, with a systematic review with or without meta-analysis. 


\section{CONCLUSION}

Social isolation can impact changes in the eating habits of different countries' populations. There was an increase in the report of the cooking habits and consumption of fruits and vegetables. On the other hand, a decrease of fish consumption and an increase in comfort foods was reported. The decrease in the consumption of alcoholic beverages should be viewed with caution, since the present review was not limited to articles that exclusively evaluated their consumption. It is suggested that further studies be carried out in different socioeconomic and demographic contexts.

\section{ACKNOWLEDGMENTS}

We are grateful to the Coordenação de Aperfeiçoamento de Pessoal de Nivel Superior (CAPES, Coordination of Superior Level Stass Improvement) for their support.

\section{CONTRIBUTORS}

LH MATSUO, C TURECK, and LP LIMA contributed to the conception and design of the study, search, collection, analysis and interpretation of data, writing of the manuscript and final version approval. PF HINNIG, EBSM TRINDADE, and FAG VASCONCELOS contributed to the conception and design of the study, analysis and interpretation of data, review and approval of the final version of the article.

\section{REFERENCES}

1. World Health Organization. WHO announces COVID-19 outbreak a pandemic 2020. Geneva: Organization; 2020 [cited 2020 Aug 2]. Available from: https://www.euro.who.int/en/health-topics/health-emergencies/coronaviruscovid-19/news/news/2020/3/who-announces-covid-19-outbreak-a-pandemic

2. Guo Y-R, Cao Q-D, Hong Z-S, Tan Y-Y, Chen S-D, Jin H-J, et al. The origin, transmission and clinical therapies on coronavirus disease 2019 (COVID-19) outbreak: an update on the status. Mil Med Res. 2020;7:11. https://doi. org/10.1186/s40779-020-00240-0

3. World Health Organization. Coronavirus Disease (COVID-19) Dashboard 2020. Geneva: Organization; 2020 [cited 2020 Aug 2]. Available from: https://covid19.who.int/

4. Ministério da Saúde (Brasil). Medidas não farmacológicas 2020. Brasília: Ministério; 2020 [citado 2 Ago 2020]. Disponível em: https://coronavirus.saude.gov.br/medidas-nao-farmacologicas

5. Garcia LP, Duarte E. Intervenções não farmacológicas para o enfrentamento à epidemia da COVID-19 no Brasil. Epidemiol Serv Saúde. 2020;29:e2020222. https://doi.org/10.5123/S1679-49742020000200009

6. Kanter R, Boza S. Strengthening local food systems in times of concomitant global crises: reflections from Chile. Am J Public Health. 2020;110:971-3. https://doi.org/10.2105/AJPH.2020.305711

7. Muscogiuri G, Barrea L, Savastano S, Colao A. Nutritional recommendations for CoVID-19 quarantine. Eur J Clin Nutr. 2020;74:850-1. https://doi.org/10.1038/s41430-020-0635-2

8. Di Renzo L, Gualtieri P, Pivari F, Soldati L, Attinà A, Cinelli G, et al. Eating habits and lifestyle changes during COVID-19 lockdown: an Italian survey. J Transl Med. 2020;18:229. https://doi.org/10.1186/s12967-020-02399-5

9. Gallè F, Sabella EA, Da Molin G, De Giglio O, Caggiano G, Di Onofrio V, et al. Understanding knowledge and behaviors related to CoViD-19 epidemic in Italian undergraduate students: the EPICO study. Int I Environ Res Public Health. 2020;17(10)3481. https://doi.org/10.3390/ijerph17103481

10. Pietrobelli A, Pecoraro L, Ferruzzi A, Heo M, Faith M, Zoller T, et al. Effects of covid-19 lockdown on lifestyle behaviors in children with obesity living in Verona, Italy: a longitudinal study. Obesity. 2020;28:1382-5. https://doi. org/10.1002/oby.22861 
11. Scarmozzino F, Visioli F. Covid-19 and the subsequent lockdown modified dietary habits of almost half the population in an Italian sample. Foods (Basel, Switzerland). 2020;9(5)675. https://doi.org/10.3390/foods9050675

12. Rodríguez-Pérez C, Molina-Montes E, Verardo V, Artacho R, García-Villanova B, Guerra-Hernández EJ, et al. Changes in dietary behaviours during the COVID-19 outbreak confinement in the Spanish COVIDiet study. Nutrients. 2020;12(6)1730. https://doi.org/10.3390/nu12061730

13. Romeo-Arroyo E, Mora M, Vázquez-Araújo L. Consumer behavior in confinement times: food choice and cooking attitudes in Spain. Int J Gastron Food Sci. 2020;21:100226. https://doi.org/10.1016/j.ijgfs.2020.100226

14. Sidor A, Rzymski P. Dietary choices and habits during COVID-19 lockdown: experience from Poland. Nutrients. 2020;12(6)1657. https://doi.org/10.3390/nu12061657

15. Zhao A, Li Z, Ke Y, Huo S, Ma Y, Zhang Y, et al. Dietary diversity among Chinese residents during the COVID-19 outbreak and its associated factors. Nutrients. 2020;12(6)1699. https://doi.org/10.3390/nu12061699

16. Nachimuthu S, Vijayalakshmi R, Sudha M, Viswanathan V. Coping with diabetes during the COVID-19 lockdown in India: results of an online pilot survey. Diabetes Metab Syndr Clin Res Rev. 2020;14:579-82. https://doi.org/10.1016/j. dsx.2020.04.053

17. Zachary Z, Brianna F, Brianna L, Garrett P, Jade W, Alyssa D, et al. Self-quarantine and weight gain related risk factors during the COVID-19 pandemic. Obes Res Clin Pract. 2020;14(3)210-6. https://doi.org/10.1016/j.orcp.2020.05.004

18. Pillay L, Janse van Rensburg DCC, Jansen van Rensburg A, Ramagole DA, Holtzhausen L, Dijkstra HP, et al. Nowhere to hide: the significant impact of coronavirus disease 2019 (COVID-19) measures on elite and semi-elite South African athletes. J Sci Med Sport. 2020;23:670-9. https://doi.org/10.1016/j.jsams.2020.05.016

19. Ammar A, Brach M, Trabelsi K, Chtourou H, Boukhris O, Masmoudi L, et al. Effects of COVID-19 home confinement on eating behaviour and physical activity: results of the ECLB-COVID19 international online survey. Nutrients. 2020;12:1-13. https://doi.org/10.3390/nu12061583

20. Maia RP, Recine E. Valores e práticas sobre alimentação de estudantes da universidade de Brasília. Demetra Aliment Nutr Saúde. 2015;10:3-25. https://doi.org/10.12957/demetra.2014.14215

21. World Health Organization. Food and nutrition tips during self-quarantine 2020. Genebra: Organization; 2020 [cited 2020 July 30]. Available from: https://www.euro.who.int/en/health-topics/health-emergencies/coronaviruscovid-19/technical-guidance/food-and-nutrition-tips-during-self-quarantine

22. Maggini S, Pierre A, Calder PC. Immune function and micronutrient requirements change over the life course. Nutrients. 2018;10(10):1531. https://doi.org/10.3390/nu10101531

23. Saini RK, Keum Y-S. Omega-3 and omega-6 polyunsaturated fatty acids: dietary sources, metabolism, and significance: a review. Life Sci. 2018;203:255-67. https://doi.org/10.1016/j.Ifs.2018.04.049

24. Lopes IG, Oliveira RG, Ramos FM. Perfil do consumo de peixes pela população brasileira. Biota Amaz. 2016;6:62-5. https://doi.org/10.18561/2179-5746/biotaamazonia.v6n2p62-65

25. Leng G, Adan RAH, Belot M, Brunstrom JM, Graaf K, Dickson SL, et al. The determinants of food choice. Proc Nutr Soc. 2017;76:316-27. https://doi.org/10.1017/S002966511600286X

26. Payab M, Kelishadi R, Qorbani M, Motlagh ME, Ranjbar SH, Ardalan G, et al. Association of junk food consumption with high blood pressure and obesity in Iranian children and adolescents: the CASPIAN-IV study. J Pediatr (Rio J). 2015;91:196-205. https://doi.org/10.1016/j.jped.2014.07.006

27. Costa CS, Del-Ponte B, Assunção MCF, Santos IS. Consumption of ultra-processed foods and body fat during childhood and adolescence: a systematic review. Public Health Nutr. 2018;21:148-59. https://doi.org/10.1017/ S1368980017001331

28. Llewellyn A, Simmonds M, Owen CG, Woolacott N. Childhood obesity as a predictor of morbidity in adulthood: a systematic review and meta-analysis. Obes Rev. 2016;17:56-67. https://doi.org/10.1111/obr.12316

29. Clay JM, Parker MO. Alcohol use and misuse during the COVID-19 pandemic: a potential public health crisis? Lancet Public Health. 2020;5(5):e259. https://doi.org/10.1016/S2468-2667(20)30088-8

30. Brooks SK, Webster RK, Smith LE, Woodland L, Wessely S, Greenberg N, et al. The psychological impact of quarantine and how to reduce it: rapid review of the evidence. Lancet. 2020;395:912-20. https://doi.org/10.1016/ S0140-6736(20)30460-8

31. Rodriguez LM, Litt DM, Stewart SH. Drinking to cope with the pandemic: the unique associations of COVID-19-related perceived threat and psychological distress to drinking behaviors in American men and women. Addict Behav. 2020;110:106532. https://doi.org/10.1016/j.addbeh.2020.106532 
32. Chodkiewicz J, Talarowska M, Miniszewska J, Nawrocka N, Bilinski P. Alcohol consumption reported during the COVID-19 pandemic: the initial stage. Int J Environ Res Public Health. 2020;17:4677. https://doi.org/10.3390/ ijerph17134677

33. Rosa LFA, Nascimento ARA. Representações sociais de bebida alcoólica para homens universitários. Arq Bras Psicol. 2015;67:3-19.

34. Richards G, Mer M, Schleicher G, Stacey S. COVID-19 and the rationale for pharmacotherapy: a South African perspective. Wits J Clin Med. 2020;2:11-8. https://doi.org/10.18772/26180197.2020.v2nSla2

35. Jukic I, Calleja-Gonzalez J, Cos F, Cuzzolin F, Olmo J, Terrados N, et al. Strategies and solutions for team sports athletes in isolation due to COVID-19. Sports. 2020;8(4):56. https://doi.org/10.3390/sports8040056

36. Prado BG, Hinnig PF, Tanaka LF, Latorre MRDO. Qualidade da dieta de escolares de 7 a 10 anos do município de São Paulo: associação com o número e os locais de refeições. Rev Nutr. 2015;28(6):607-18. https://doi.org/10.1590/141552732015000600004

37. United Nations Development Programme. Human development report 2019. New York; 2019 [cited 2020 July 30]:352. Available from: http://hdr.undp.org/sites/default/files/hdr2019.pdf 